Jusmal lemiah
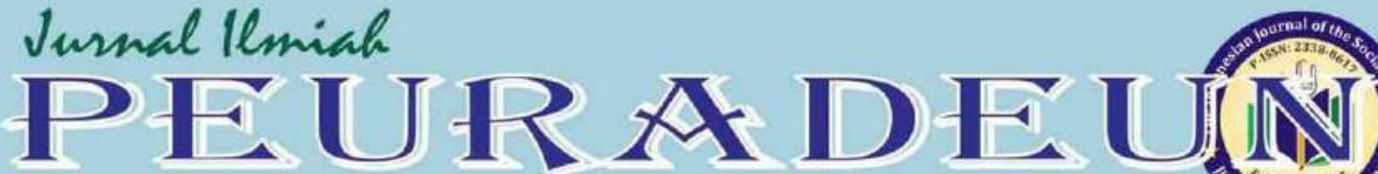

Vol. 8, No. 3, September 2020

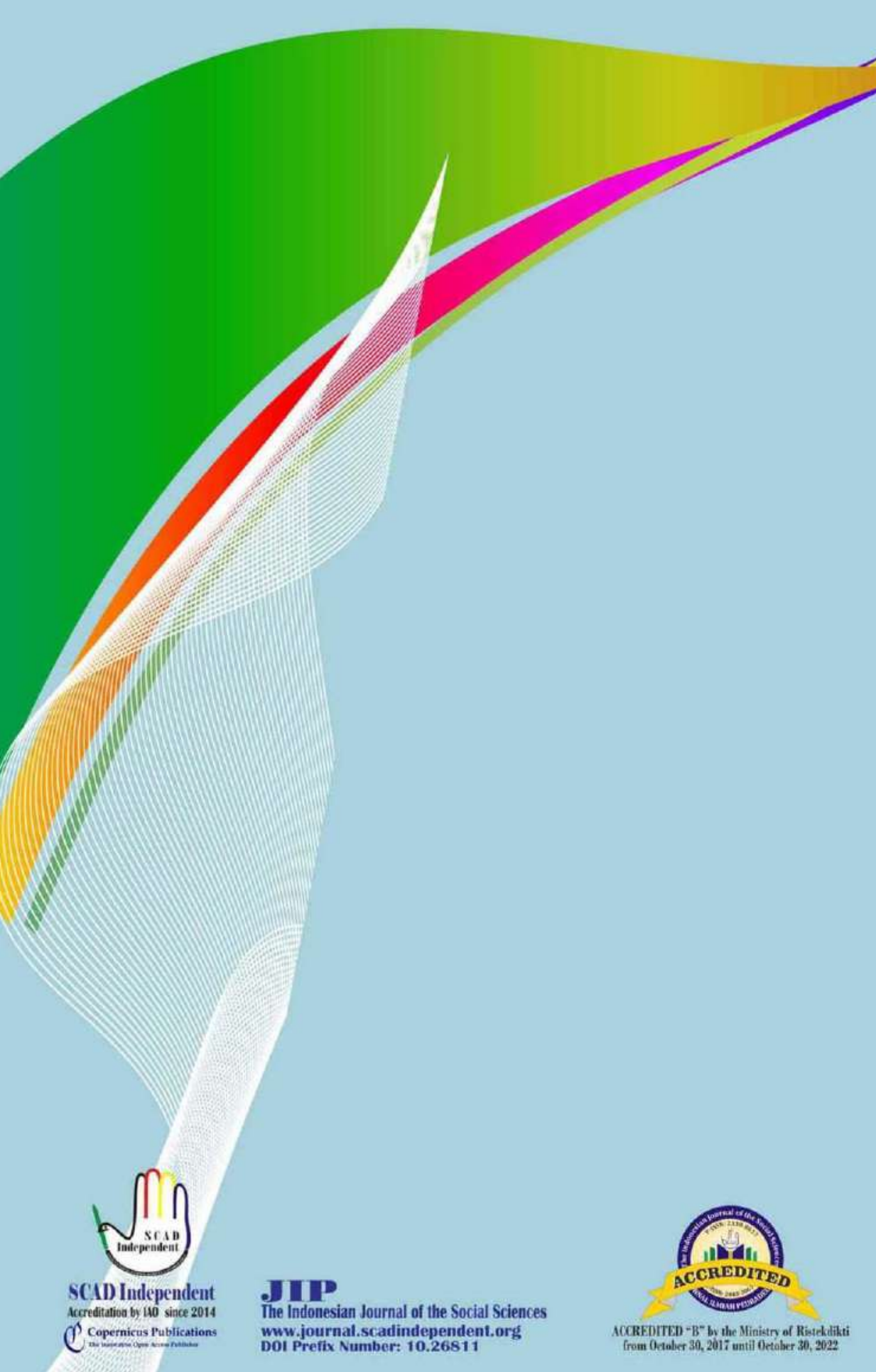

\section{Clarivate Analytics}

Emerging Sources Citation Index Web of Science ${ }^{\mathrm{TM}}$

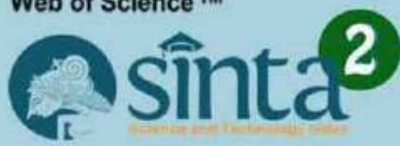

INDEX $\circledast$ COPERNICUS www.journal.scadindependent.org Dot Prefix Number: 10.2681 


\author{
JURNAL ILMIAH PEURADEUN \\ The Indanesian Journal of the Sacial Sciences \\ p-ISSN: 2338-8617/ e-ISSN: 2443-2067
}

www.journal.scadindependent.org

\author{
Vol. 8, No. 3, September 2020
}

Pages: 531-552

\title{
An Analysis of Psychological Trauma and Depression of Survivors in Recurring Disaster
}

\author{
Elvi Suryana1; Nizamuddin²; Agus Sabti ${ }^{3}$ Imran $^{4}$; \\ Syahrul5; Marty Mawarpury ${ }^{6}$ \\ 1,2Master of Disaster Science, ${ }^{3}$ Faculty of Agriculture, 4,5,6 Faculty of Medicine, \\ Universitas Syiah Kuala, Indonesia
}

\begin{abstract}
Article in Jurnal Ilmiah Peuradeun
Available at : https://journal.scadindependent.org/index.php/jipeuradeun/article/view/511

DOI $\quad$ : http://dx.doi.org/10.26811/peuradeun.v8i3.511
\end{abstract}

\begin{abstract}
How to Cite this Article
APA : Suryana, E., Nizamuddin, N., Sabti, A., Imran, I., Syahrul, S., \& Mawarpury, M. (2020). An Analysis of Psychological Trauma and Depression of Survivors in Recurring Disaster. Jurnal Ilmiah Peuradeun, 8(3), 531-552. doi:10.26811/peuradeun.v8i3.511
\end{abstract}

Others Visit : https://journal.scadindependent.org/index.php/jipeuradeun

Jurnal Ilmiah Peuradeun (JIP), the Indonesian Journal of the Social Sciences, is a leading peer-reviewed and openaccess journal, which publishes scholarly work, and specializes in the Social Sciences that emphasize contemporary Asian issues with an interdisciplinary and multidisciplinary approach. JIP is published by SCAD Independent and published 3 times of year (January, May, and September) with p-ISSN: 2338-8617 and e-ISSN: 2443-2067. Jurnal Ilmiah Peuradeun has become a CrossRef Member. Therefore, all articles published will have a unique DOI number. JIP has been accredited by the Ministry of Research Technology and Higher Education Republic of Indonesia (SK Dirjen PRP RistekDikti No. 48a/KPT/2017). This accreditation is valid from October 30, 2017 until October 30, 2022.

JIP published by SCAD Independent. All articles published in this journal are protected by copyright, licensed under a CC-BY-SA or an equivalent license as the optimal license for the publication, distribution, use, and reuse of scholarly works. Any views expressed in this publication are the views of the authors and not of the Editorial Board of JIP or SCAD Independent. JIP or SCAD Independent cannot be held responsible for views, opinions and written statements of authors or researchers published in this journal. The publisher shall not be liable for any loss, actions, claims, proceedings, demand, or costs or damages whatsoever or howsoever caused arising directly or indirectly in connection with or arising out of the use of the research material. Authors alone are responsible for the contents of their articles.

JIP indexed/included in Web of Science, MAS, Index Copernicus International, Sinta, Garuda, Moraref, Scilit, Sherpa/Romeo, Google Scholar, OAJI, PKP, Index, Crossref, BASE, ROAD, GIF, Advanced Science Index, JournalTOCs, ISI, SIS, ESJI, SSRN, ResearchGate, Mendeley and others. 


\title{
AN ANALYSIS OF PSYCHOLOGICAL TRAUMA AND DEPRESSION OF SURVIVORS IN RECURRING DISASTER
}

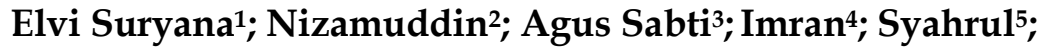 \\ Marty Mawarpury ${ }^{6}$ \\ ${ }^{1,2}$ Master of Disaster Science, ${ }^{3}$ Faculty of Agriculture, ${ }^{4,5,6}$ Faculty of Medicine, \\ Universitas Syiah Kuala, Indonesia \\ ${ }^{1}$ Contributor Email: elvisyifafayza@gmail.com
}

Article Url: https://journal.scadindependent.org/index.php/jipeuradeun/article/view/511

\begin{abstract}
The study aimed to determine psychological trauma and depression in survivors of recurring disasters (the 2004 and 2012 earthquakes in Aceh). A quantitative approach was used as the research design, 2 villages located in Banda Aceh were taken as the samples involving 60 respondents from the two villages. The respondents' criteria were: 1) experiencing two earthquakes in 2004 and 2012,2) aged over 30 years. Data collection used a modification of the Hamilton Anxiety Rating Scale questionnaire, depression scale, and demographic data. The results showed that there was no correlation between psychological trauma and depression in survivors of the recurring earthquake in Aceh. Besides, based on the results of data analysis, there was a correlation between symptoms $(p \leq 0,000)$, occupation $(p \leq 0,030)$, and age $(p \leq 0,015)$ with psychological trauma; and there was no correlation between potential disasters $(p \leq 0,075)$, family support $(p \leq 0,002)$, education $(p \leq 0,181)$ coping ability $(p \leq 0,401)$, the value of faith $(p \leq 0,266)$, and income $(p \leq 0,830)$ with psychological trauma.
\end{abstract}

Keywords: Psychological Trauma; Depression; Earthquake; Survivor 


\section{A. Introduction}

A disaster is a serious disruption on community function that causes loss expanding to human life, either to the economy, public order, or environment (LIPI, 2006). According to Act No. 24 the year 2007, disaster is an event or a sequence of events, threatening and disturbing people's lives and livelihood, is caused either by natural, non-natural or human factor hence resulting in loss of life, environmental damage, loss of property, and psychological impact.

Indonesia has a high vulnerability of natural disasters such as volcano eruptions, earthquakes, tsunami, floods, landslides, and so on. Moreover, Indonesia becomes one of several nations with a high earthquake rate in the world, ten times higher than The United states' earthquake rate. Aceh is a province in Indonesia with earthquake vulnerability and becomes the potential to the tsunami. According to the data of The Rehabilitation and Reconstruction Agency in 2005, the impact of earthquake and tsunami in 2004 was that 167.000 people got killed or missing, and more than 500.000 people became refugees (TDMRC, 2011).

The 8.8 magnitude earthquake, centered in southwest Simeulue in Aceh happening on April 11'th 2012 , reminded about the great earthquake and tsunami happening in 2004. In that event, people were panic, crowded on the street, crushed, jostled, and got through one another with the motorcycle to go away from the beaches. It happened because people had ever experienced a traumatic event previously. A traumatic event is classified into three important elements, first, when the event happens is unpredicted, second, people experiencing the event are not ready to face it, third, they cannot prevent the event (Adesla, 2009).

Trauma is a serious physical or emotional injury that substantially impacting on an individual's psychological and physical in the long term (Weaver, Flannelly, and Preston, 2003). Based on mental health, and unhealthily solved traumatic events can raise psychological trauma, however, if the problem can be healthily and effectively solved, the psychological trauma can be healed and possibly to emerge people's ability to minimize the bad impact of a disaster. 
According to Ulfah (2013), $70-80 \%$ of people who have experienced a traumatic event of disaster show distress mental symptoms like fear, sleep disturbance, bad dream, panic, excessive alertness, grief, etc. the symptoms are normal responses in an abnormal situation like a disaster. However, generally, this condition is temporary, mostly it is healed naturally over time, only $20-30 \%$ cases of severe mental disorder. Every person or survivor of a disaster is at risk of suffering from PTSD, from children to adults or even elders (Jirwo, 2012).

After 10 years of disaster in Aceh, it is important to see the condition of survivors' mental health, especially those who experienced a recurring earthquake with relatively similar magnitude. Therefore, this research investigated the trauma and depression of recurring earthquake survivors in Aceh.

\section{B. Literature Review}

\section{Trauma}

Trauma is a serious physical or emotional event that causes substantial damage to one's physical and psychological in a relatively long time (Weaver, Flannelly, and Preston, 2003). Supratiknya (1995) explains that psychological trauma can destroy the feeling of safety, ability, and self-esteem so that it emerges difficultly-healed injury. The victim will experience disequilibrium in one's mental and emotional. According to Willey \& Sons (2008), Psychological trauma is a condition occurring due to shocking and frightening event which endangers to physical or psychological, or even death.

A disaster has a different effect on each individual, some individuals will not suffer from significant psychological effects, while others will get agitated emotionally. The behaviors expressed by those who experience a disaster are various, it is affected by perception about the disaster itself, by supporting system and coping mechanism. There are three steps of emotional reaction after a disaster, as follows:

a. An Individual's immediate reactions (first 24 hours) after the disaster are being tense, anxious, panic, stock-still, dazed, shocked, unbelievable, happy, or euphoria, not very anguish, tired, confused, restless, crying, 
withdrawing, and guilty. Those reactions are still normal reactions toward the abnormal situation and need primary prevention.

b. First until the third week after the disaster. The reactions are: frightened, alert, sensitive, easy to get angry, difficult to sleep, worried, and very sad. Meanwhile, the positive reactions are: hopeful or thoughtful about the future, being involved in rescuing and helping activity, accepting the disaster as a fate. The conditions above are normal responses which require minimum psychosocial action.

c. More than three weeks after the disaster. The reactions can stay and be manifested in form of exhaustion, panic, sadness, pessimistic, withdrawal, unrealistic thinking, no activity, isolation, anxiety in form of palpitation, dizziness, tiredness, nausea, and headache (Keliat et al, 2011).

\section{Depression}

Depression is a lower mood disorder and is characterized by depressive affect, loss of interest and happiness, low energy resulting in tiredness and lack of activity. The mood is defined as a deep and settling feeling which is internally experienced and influences one's behavior and perception about the world. The depression can be influenced by a discrimination attitude that is characterized with no hope, being heartbroken, being excessively helpless, no spirit of life, being unable to decide to start an activity, being unable to concentrate, being always tense and being suicidal (Soejono and Probosuseno, 2009).

\section{Understanding of Information about Warning and Risk of Disaster}

Wicken \& Holland (in Rice, 2010) state than in information processing theory, an individual's responding ability can be seen through one's cognitive process steps to be able to determine the proper response in facing a disaster. The steps are:

a. Ability to collect information and detect the possibility of danger;

b. Ability to analyze and interpret the signs of severity and risk level of a disaster; 
c. Ability to assess the risk that they perceive;

d. Ability to act based on the process of taking on decision making

According to Paula and Gordon (2003), trauma is caused by several things, as follows: Natural disaster, man-made disaster, loss of logic, conflict, and violence. Parkinson (2000) explains that a traumatic event can happen during a disaster until the disaster passes, in the latter condition, it is called PTSD. The left trauma will continuously exist in oneself who suffers from a horrible event. The tendency of PTSD will be present if no integrated mental treatment is conducted. Cognitive process in information processing can be seen in the figure below:

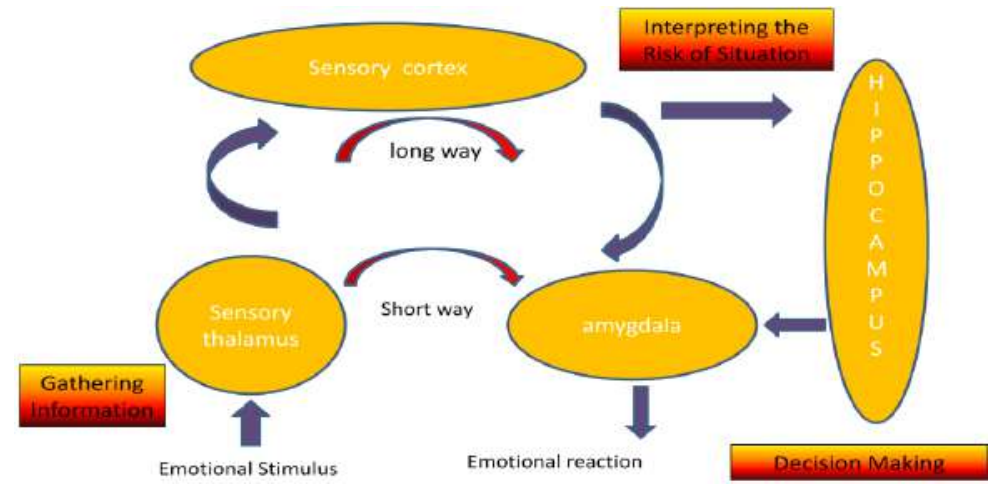

Figure 2.2 Information Processing

Source : EMDR Institute, 2010

According to Langan et al (2005), information processing happens when data or information gets into brain through senses. The chart above shows the process as follows, if an individual receives information about danger, one will respond by long way process that is through accepting coming stimuli (encoding) by sensory thalamus, like earthquake. The data and information are then analyzed by cerebral cortex (1) to see the correlation between one information and other and to mediate with limbic system which is a central of emotion regulation. Limbic system, amydala (2) will absorb the meaning of the information sent by cortex in form of anxiety, fear, anger, and so on. Sensory cortex will consolidate with a part called hippocampus (3). Hippocampus, part of limbic system, functions to store rational memory especially short-term memory and has an essential role to transfer new memory to long-term storage. 
If rational information about danger is received by the hippocampus, it will form new knowledge and will be forwarded to the amygdala which will emerge certain emotional reactions. The process also activates hypothalamic pituitary-adrenal (HPA) which produces corticotrophin hormone, so that it triggers the activation of adrenocorticotropic hormone (ACTH). It will emerge a response in autonomic nervous system which then reacts "fight" (try to face a danger) or "flight" (try to avoid or save oneself from a danger), they are called alarm phase. The coming response will involve physiological, emotional, cognitive and behavioral reactions. The reactions are also influenced by developmental phase, maturity, and previous experience and cultural background (Langan et al, 2005).

\section{Method}

This research used quantitative approach with survey method to know the factors that influence the level of psychological trauma during recurring earthquake disaster. The research was conducted in Punge Blang Cut and Punge Ujong village, Jaya Baru sub-district Banda Aceh city. The population was both villages that suffered from recurring earthquake. The samples were 30 villagers of Punge Blang Cut village and 30 villagers of Pungo Ujong village, who experienced recurring earthquake in 2004 and 2012. The data source of this research consist of primary and secondary data. The secondary data were obtained from library and field research as well as from the research-related instituions. Meanwhile, primary data were obtained from observation, structured and unstructured interview. The questionnaire in this research was taken from HARS and modification from researcher.

Data analysis to know the level of psychological trauma in recurring earthquake was processed by using:

1. Descriptive statistic, as follows:

$$
P_{n}=\frac{F}{N} \times 100 \%
$$




\section{Elvi Suryana et al.}

Description:

$P_{n}=$ Percentage of psychological trauma level in recurring earthquake, $(\mathrm{n}=1,2, \ldots .7),(\mathrm{n}=1$ : signs and symptoms, $\mathrm{n}=2$ : disaster potential, $\mathrm{n}=3$ : age, $\mathrm{n}=3$ : education, $\mathrm{n}=4$ : family support, $\mathrm{n}=5$ : value of belief, $\mathrm{n}=6$ : income, $\mathrm{n}=7$ : coping ability).

$f=$ recurring earhquake event

$N=$ total of recurring earthquake events

2. Bivariate analysis was used to know the correlation between independent variable and dependent variable through cross table analysis by using computerized program with condition: if p.value $\geq 0.05$, Ha is rejected, if p.value $<0.05$, Ha is accepted.

3. Multiple correlation analysis was done to know the factors that influence level of psychological trauma in repeated earthquake event. The result of correlation analysis was further proven in multiple linear regression analysis. This method was used to know the correlation among variables if there are more than 2 variables. Multivariate test is used to know any correlation among independent variables. To know independent variable that is most influential to dependent variable, multiple regression analysis was employed in significance level of $95 \%$ ( $p$ value $=0,05$ ) (Budiarto, 2013). Value interpretation " $r$ " can be seen in 3.4. below:

\begin{tabular}{cc}
\hline $\mathbf{R}$ & Interpretation \\
\hline $0,21-0,40$ & Low \\
$0,61-0,80$ & Moderate \\
$0,81-0,99$ & High \\
\hline Source: Usman E Purnomo (2000)
\end{tabular}

\section{Results and Discussion}

\section{Results}

Demographic data of Punge Blang Cut and Punge Ujong Village, Jaya Baru Sub-District, Banda Aceh City can be seen in the table below.

Table 1. Distribution of respondents' characteristic frequency $(\mathrm{n}=60)$

\begin{tabular}{|l|c|c|}
\hline \multicolumn{1}{|c|}{ Characteristics } & F & $\%$ \\
\hline $\begin{array}{l}\text { Sex } \\
\text { Fale }\end{array}$ & 34 & 56.7 \\
\hline
\end{tabular}




\begin{tabular}{|l|c|c|}
\hline \multicolumn{1}{|c|}{ Characteristics } & F & $\%$ \\
\hline Occupation & 26 & 43.3 \\
\hline Permanent workers & & \\
Part-time workers & 23 & 38.3 \\
\hline
\end{tabular}

Table 1 shows that majority of respondents are part-time workers for $61.7 \%$, majority are male for $56.7 \%$ ). Those part-time workers are laborers, merchants, and farmers.

\section{a. Frequency of psychological trauma and depression during Earthquake disaster}

Table 2. Distribution of frequency of psychological trauma and depression during earthquake disaster among Banda Aceh people who faced earthquake on December 26th, 2004 and April 11st, $2012(\mathrm{n}=60)$

\begin{tabular}{|c|c|c|}
\hline Psychological Trauma & $F(n=60)$ & $\%$ \\
\hline High (58-75) & 11 & 18.3 \\
\hline Moderate (42-57) & 31 & 51.7 \\
\hline Low (25-41) & 18 & 30.0 \\
\hline Depression & $F(n=60)$ & $\%$ \\
\hline High (36-45) & 4 & 6.6 \\
\hline Moderate (25-35) & 22 & 36.7 \\
\hline Low $(15-24)$ & 34 & 56.7 \\
\hline
\end{tabular}

Table 2 shows that majority of psychological trauma during earthquake is at moderate level for $51.7 \%, 30.0 \%$ low and $18.3 \%$ high. Trauma during earthquake disaster is mostly at moderate which is indicated by the symptoms that mind or repeatedly arise memory about most hurt or horrible event experienced by people reminds them about what they experienced. Those who are at high earthquake disaster trauma are mostly indicated by the event that would not happen again, moreover they realize that they have a lot of feeling about the earthquake event like it is frozen on their memory. Meanwhile, those with low trauma are indicated that they never experience strong emotion symptom that is related with earthquake event, they also keep alert and try to not talk about it.

Table 2 shows that majority of depressions among people are at low level for $56.7 \%$, moderate $36.7 \%$, and high $6.6 \%$. trauma-caused depressions during earthquake event are mostly moderate, it is caused by people who feel 
guilty to what happen to them, so that they suffer from high depression and become uninterested in doing their activity. Those who are at high level of earthquake-caused depression are mostly indicated that they frequently have appetite disorder (reducing), difficult to sleep, worry and easily to be awake, feel no future hope. Those with low trauma indicate symptom of no need of effort and difficulty, they never feel trapped, never feel unable to get out of a situation and never worry about recurrent earthquake.

\section{b. Frequency of factors that influence people in facing recurring earthquake}

Table 3. Factors that influence people in facing the 2004 and 2012 earthquake $(\mathrm{n}=60)$

\begin{tabular}{|c|c|c|}
\hline Disaster Potential & f & $\%$ \\
\hline High (12-15) & 31 & 51.7 \\
\hline Moderate (8-11) & 24 & 40.0 \\
\hline Low (5-7) & 5 & 8.3 \\
\hline \multicolumn{3}{|l|}{ Signs and Traumatic Symptoms } \\
\hline High (21-27) & 17 & 28.3 \\
\hline Moderate (15-20) & 31 & 51.7 \\
\hline Low $(9-14)$ & 12 & 20.0 \\
\hline \multicolumn{3}{|l|}{ Age } \\
\hline Young ( $\leq 35$ year old) & 35 & 58.3 \\
\hline Adult (36-55 year old) & 15 & 25.0 \\
\hline Old (> 55 year old $)$ & 10 & 16.7 \\
\hline \multicolumn{3}{|l|}{ Value of Faith } \\
\hline High (15-15) & 46 & 76,7 \\
\hline Moderate (8-11) & 13 & 21,6 \\
\hline Low (5-7) & 1 & 1,7 \\
\hline Family Support & & $\%$ \\
\hline High (10-12) & 20 & 33.3 \\
\hline Moderate (8-9) & 33 & 55.0 \\
\hline Low (5-7) & 7 & 11.7 \\
\hline \multicolumn{3}{|l|}{ Education } \\
\hline Higher (DIII/Bachelor) & 12 & 20.0 \\
\hline High (SMA/SMK/MAN) & 30 & 50.0 \\
\hline Junior/elementary (SD/SMP) & 18 & 30.0 \\
\hline \multicolumn{3}{|l|}{ Income } \\
\hline High ( $\geq$ Rp. 4.500.000,-) & 8 & 13.3 \\
\hline Middle (Rp. 1.550.000-4.500.000) & 43 & 71.7 \\
\hline Low (<Rp. 1.550.000,-) & 9 & 15.0 \\
\hline Coping Ability & f & $\%$ \\
\hline High (10-12) & 26 & 43.3 \\
\hline Moderate (8-9) & 24 & 40.0 \\
\hline Low (5-7) & 10 & 16.7 \\
\hline
\end{tabular}




\section{c. Correlation between psychological trauma and depression}

From analysis, it is known that there is correlation between psychological trauma and depression based on correlation score for 0.042 $(p=0.749)$. Interpretation on level of correlation among variables in this research was done by seeing coefficient of correlation number as the result of calculation using $r$ value interpretation, as follows: (Sugiyono, 2007) from the data above, it can be concluded that depression variable $(X)$ and psychological trauma variable $(\mathrm{Y})$ are significantly correlated because the correlation score is 0.749 .

\section{d. Psychological trauma and depression-related factors on recurring earthquake}

Multivariate analysis was done to know factors that are related to psychological trauma and depression on recurring the 2004 and 2012 earthquakes among Banda Aceh people, as follows:

Table 4. Analysis of factors that are related to psychological trauma on recurring 2004 and 2012 earthquake among Banda Aceh People

\begin{tabular}{lccc}
\hline Variables & p.value & $\mathrm{R}$ & $\mathrm{R}$ Square \\
\hline Occupation & 0.030 & & \\
Age & 0.015 & & \\
Education & 0.181 & & \\
Income & 0.830 & & \\
Trauma Symptoms and Signs & 0.000 & 0,221 & 0,049 \\
Disaster Potential & 0.075 & & \\
Family Support & 0.415 & & \\
Value of Faith & 0.266 & & \\
Coping Ability & 0.401 & & \\
\hline
\end{tabular}

Based on regression analysis, the conclusion is that occupation, age and trauma symptoms and signs variables are influential to psychological trauma, while education, income, disaster potential, family support, value of faith and coping ability are not influential to psychological trauma of recurring earthquake.

$R$ value is the symbol of confident, in the table 4, correlation score is 0.221 . The value can be interpreted that variables correlation in this research is at sufficient category. The table also shows $\mathrm{R}$ Square value or coefficient of determination which shows the quality of regression model 
which is formed by interaction of independent and dependent variables. Coefficient of correlation score is $0.49 \%$. So that independent variable $\mathrm{X}$ contributes for $0.49 \%$ on variabele $Y$.

\section{Discussion}

Masykur (2006) states that psychologically disaster victim suffers from imbalance mental and emotion, if it is prolonged and is not adequately managed, the victim will suffer from dangerous disorder called Post Traumatic Stress Disorder (PTSD) which is usually suffered by those with extremely traumatic stressor. The victim will potentially suffer from traumatic aspects, panic, paranoia, insomnia, excessive guilty feeling, unstable emotion, agitated memory and concentration, fear of seperating and loss, fear of death, disorientation, agression and even the unexpected severe condition, in form of mental function disorder (psychosis) or even suicide. According to Soejono and Probosuseno (2009), depression can be influenced by discrimination attitude in form of no hope and broken heart, excessive helplessness feeling, no spirit of life, unable to decide to start an activity, unable to concentrate, tense and being suicidal.

Research by Sumarno (2013) about psychological impact after being trauma caused by Merapi eruption shows that trauma-caused psychological impacts which are suffered by the subjects are always remembering the traumatic event (intrusive re-experiencing) of Mearapi eruption disaster. The efforts to handle post traumatic psychological impacts are establishing the intention and getting close to Allah as the most glorified and the most high God, being involved in social and cultural activity and getting involved in therapy in form of relaxation and games.

Based on the result of this research, majority of earthquake potential is at high category for $51.7 \%$. It is important to identify the disaster prone area in Banda Aceh city in order to prevent people's panic. Disaster potential of earthquake is mostly high, because people disbelieve that the earthquake could be prevented by adequate knowledge, and they disbelieve that earthquake potential is caused by geological order and assemble of three earth plates. Those who tend to have earthquake 
potential generally less understand about the importance of prone areas identification to improve people mitigation through education. Those with low earthquake potential are mostly from people who feel right about mitigation as an effort to reduce disaster risk.

According to Nawangsih (2014), grief-emerging disasters make its victims feel that they are in a very uncomfortable condition, frightened, and restless. In addition, the victims become easily panic. Panic attacks emerge intense anxiety reaction along with physical symptoms like heartbeat, fast breath, wheezing breath, or difficult breath, much sweating, being weak and dizzy. The attacks are along with terror feeling and feeling about danger or misery that would happen. Coursol et al, (2001) explain that an aspect of individual function that is probably affected by the presence or traumatic event is one's ability to be involved in career and activity that are related to occupation to reach one's potential optimally. Until today, there are limited discussion and research about the correlation between traumatic symptoms, career development and vocational behavior.

Traumatic event can be felt again in various forms. Mostly, it is in form of repeated and disturbing memory, or repeated frightening dream about the event for seconds, hours, or even days, and the victim's identity could change. Over the period, the traumatic event is felt as if it were reexperienced. The victim will behave like the moment in which the event used to happen. The victim will suffer from great major distress in which the excessive reaction of physiological function is present, if the victim is exposed with trauma-triggered event or the similar condition, or even the thing that represents the event one has experienced.

Based on aspect in human, there are some symptoms that are present due to psychological trauma that is suffered by an individual as follows, physical, emotional and cognitive aspects. The most frequent symptoms post-trauma are: (1) warm body: fever with increasing body temperature, (2) dry throat: being lazy to have a meal due to dry throat, being difficult to swallow food, or even tasting bitter, (3) tiredness: feeling frequently tired, (4) nausea: uncomfortable stomach, desiring to vomit, (5) weak body: for kids, they usually feel sluggish and being fussy, (6) chest 
pain: frequent cough, complaining chest pain, (7) fast heartbeat: usually the heartbeat normal, but post-trauma makes it faster (Hatta, 2015).

Table 4 shows that majority signs and symptoms are at moderate category for 31 people or $51.7 \%$. it is because people feel sad if the disaster is recurring, some of whom remember the past failure. Those that are indicated with moderate trauma signs and symptoms sometimes lose desire and become panic during earthquake. According to Mr. A, one of the respondents, if the strong earthquake happens, they will run to their home and get into PLTD Apung ship as they did when the earthquake happened in Aceh Jaya on December $7^{\text {th }}$ with 6.5 magnitudes. Meanwhile, those with high potential earthquake disaster feel sad when the earthquake happen, they feel pessimistic and anxious, and they frequently cry. Those with low earthquake potential never lose their interest during earthquake, and they never feel guilty.

Kinchin (2007) says that a horrible event that is experienced by an individual becomes a memory that decorates emotional network. The symptoms are sign that Amygdala gets too much shock, therefore it forces the memory about the event keep coming into consciousness. Traumatic event can grow the triggering memory in Amygdaya, like: being safe from drowning ship, bombing, fire, earthquake, robbery, rape, and etc. Research by Kun et al. (2009) explained that earthquake victims in Wenchuan, China, suffered from stress and concentration disorder after earthquake. The research also explained that the respondents whose family passed away more suffered from post trauma stress. Meanwhile, Fan et al. (2011) assessed PTSD symptoms, anxiety and depression, on adolescents for six months after earthquake in Wenchuan, China. The result showed that $15.8 \%, 40.5 \%$, and $24.5 \%$ of participants suffered from clinical symptoms of PTSD, anxiety and depression in a row. Risk factors of those three disorders were mostly suffered by women, elder, and directly experiencing the earthquake.

When facing terribly traumatic event, most people may not suffer from PTSD. However, ordinary event could present PTSD symptoms for most people. It is caused by risk factor that role whether someone will get 
PTSD or not. The risk factors are: the existence of childhood trauma, those with personality disorder (such as: borderline, paranoid, addiction or antisocial), inadequate support system from family and peers, sex: female, genetic susceptibility of mental illness, life changing with full of stress/pressure, external perception on locus of control, and excessive alcohol intake (Sadock and Sadock, 2007).

Besides symptoms and signs of trauma, age becomes natural factor that cannot be changed, so that it is important to improve controlling and management of risk to prevent illness when coming into certain age. chronological age (calendar) of human can be classified in various periods, child, adolescence, adulthood, for some women it does not have psychological problem, yet for some others it does, including depression and amnesia. Table 4.6 shows that average ages are at young age ( $\leq 35$ year old) for 35 people $(58.3 \%)$, this is dynamic age yet not psychologically mature. The youths ( $\leq 35$ year old) are generally indicated with the understanding about earthquake, because they are easy to search for information about an event and symptoms. Meanwhile, some of adults (36-55-year-old) are not dynamic enough, however their understanding about one thing is more mature psychologically. The oldster $(>55)$ become more difficult to understand about and search for earthquake-related information because at their age they are not dynamic anymore yet psychologically mature. Research by Tukan (1993) shows that at early adulthood the youths coming into family period prepare themselves to succeed their family life. A man's mindset is usually objective and one mostly tends to have long-term thought (future thought).

Belief in God has a role in forming people's acceptance toward post-disaster condition that they experience. Strong grief suffered from the survivors of disaster emerges deep trauma, the survivors suffer from maladaptive reaction emerging after experiencing traumatic event. Table 4.7 shows that value of people's faith is high $(76.7 \%)$. They with high faith are indicated that because they often think that religion creates its own interpretation on disaster cause. In addition, they after think that 
earthquake happens because of God's will, as a respondent told that all disasters in the earth have something to do with God's will, we, as the creatures, can only make effort while doing positive thing. Meanwhile, they with moderate value of faith are indicated that they believe the disaster is caused by humans who neglect to environment hence earthquake happens, while only one has low value of faith, he never believes that earthquake is caused by fortune and God's will.

Research by Argyle (2001) shows that religiosity helps somebody maintain their mental health during hard condition. Furthermore, research by Ellison (in Taylor, 1995) shows that religion could improve one's psychological well-being. Ellison's research shows that an individual with high faith on religion is reported to have high life satisfaction, high personal happiness, and experience fewer negative impacts of traumatic event than that with low faith on religion. Research by Syofian (2008) on religion as rehabilitation instrument for earthquake victims' trauma (research on activity of volunteers from UIN Sunan Kalijaga in Jomblangan Bangun Tapan sub-district Yogyakarta) shows that believed religion could become a solution in every life problem', religion is considered adaptable to approach the earthquake victims.

According to Ancok and Suroso (1994), there are five dimensions of religiosity, as follows: 1. Ideological dimension, level of an individual's acceptance on dogmatic matters in one's religion such as belief in God, heaven, and hell. 2. Intellectual dimension, to what extent an individual know one's religion teachings, especially those in scripture. 3. Ritualistic dimension, level of an individual's practice on one's religion ritual such as salat, zakat, fast, and hajj. 4. experiential dimension, feelings or experiences of religion that are ever experienced and felt such as a feeling of being close to God, a feeling of being protected by God, and a feeling of being answered by God. 5. Consequential dimension, a dimension measuring to what extent one's behavior in social life is motivated by religious teaching like visiting one's sick friend and helping one's friend with misfortune.

The result of this research is in accordance with Amawidyati \& Utami research that is known that based on product moment correlation 
there is significantly positive correlation between religiosity and psychological well-being of earthquake victims $(r=0.505 ; \mathrm{p}<0.05)$.That result shows that the higher religiosity score, the higher psychological wellbeing of earthquake victims and vice versa. Determination coefficient score (R2) obtained from data analysis is 0,255 . That score means that religiosity has role on psychological well-being of earthquake victims for $25.5 \%$. In this term, value of faith could provide the sources to explain and solve problematic situation, improve the feeling of being empowered and efficacy of oneself, and become base of feeling of being meaningful, having way, personal identity, and potentially grow a meaningfully strange event.

Family support is very worth and important for survivors. This research finds that majority of family supports toward the people are at high category for $55 \%$. Those with moderate family support are indicated that they sometimes consider family giving attention to them and family has an active role in every condition during the earthquake. Those with high family support are indicated that their family often provides information about the effect of earthquake, and their family often exchanges ideas during earthquake moment. Meanwhile, those with low family supports never have their family give attention to them during earthquake, and never provide information about earthquake impact.

People with PTSD are expected to have family supports from parents, teachers, brothers, peers, and society hence they have confidence, have a feeling of being accepted, cared, recognized, and are able to have a normal life (Tentama, 2014). In term of handling PTSD in Banda Aceh posttsunami, it should be comprehensive and involve people. People with strong kinship system have family network which is considered strategic in helping recovery besides broader social environment. According to Friedman (1998), emotional supports consist of empathy expression, caring and attention from relatives to family members. Caplin (in Yuliani, 2002) describes social support as well formal or informal relationship of one another in an environment. Supports obtained by an individual from family, friends, and other people are related to one's well-being. 
The result shows that majority of respondents' educations are at moderate category $(50,0 \%)$. Those at moderate category are indicated at High School. Those at high category are indicated having knowledge about earthquake, the signs, symptoms and prevention, while those at low category are indicated never obtain information and knowledge about earthquake. Priyanto (2006) says that people with higher education are more capable to decrease the risk, improve ability and reduce impact on health, therefore they participate in better way as individual or society in facing disaster. Some factors of the increasing victim are lack knowledge of society on disaster and lack of readiness in anticipates the disaster. Particularly for earthquake, the death toll is high because being struck down by the collapsing building. Most of the fatalities are women and children. There is an action in management of disaster risk called disaster risk reduction measure.

Coping is more directed to what people do to overcome the pressuring demand or emotion-raising demand. On the other words, coping is one's reaction in facing stress or pressure (Siswanto, 2007). Table 4 shows that majority of the people's coping are at high category for 26 people $(43.3 \%)$. Those with high coping ability are never attempt to clear up the cause of trauma due to earthquake; they also never seek for deep information about the correlation between stress and disaster, especially earthquake. Those with moderate-leveled coping are closer to God and after think about the step that they should take to overcome earthquakecaused problems, while those with low coping often seek for information about the correlation between stress and disaster, especially earthquake, they also frequently think about the way that they have to take in overcoming earthquake problem.

Wiramihardja (2005) states that an individual who experiences horrible or frightening event or those with anxious experience are unable to do self-identification, have no rational thought, have no realistic sources about the anxiety they suffer from. It cannot be denied that the result of this research supports the hypothesis that trauma symptoms hamper cognitive functions that are related to development of solid 
vocational identity (such as having clear vocational values, having interest, and awareness of oneself basic needs) and the symptoms are potentially contrary to implementation of career goal . On the other words, those symptoms will emerge negative psychological impact, the essence of which is fear and anxiety.

\section{E. Conclusion}

Trauma is a serious physical or emotional injury that substantially impacting on an individual's psychological and physical in the long term. Based on mental health, and unhealthily solved traumatic events can raise psychological trauma, however, if the problem can be healthily and effectively solved, the psychological trauma can be healed and possibly to emerge people's ability to minimize the bad impact of a disaster.

An individual who experiences a horrible or frightening event or those with anxious experience is unable to do self-identification, have no rational thought, has no realistic sources about the anxiety they suffer from. It cannot be denied that the result of this research supports the hypothesis that trauma symptoms hamper cognitive functions that are related to the development of solid vocational identity (such as having clear vocational values, having interest, and awareness of oneself basic needs) and the symptoms are potentially contrary to implementation of career goal. In other words, those symptoms will emerge negative psychological impact, the essence of which is fear and anxiety.

\section{Bibliography}

Amir, N. (2005). Depresi Aspek Neurobiologi Diagnosis dan Tatalaksana. Jakarta: FK UI.

Ancok, D, dan Suroso, N. S. (1994). Psikologi Islami. Jakarta: Pustaka Pelajar.

Argyle, M. (2001). The Psychology of Happiness. 2nd Edition. Sussex: Routledge.

Azwar, Azrul. (1996). Pengantar Administrasi Kesehatan Masyarakat. Edisi Ketiga. Jakarta: Bina Rupa Aksara. 
Elvi Suryana et al.

Badan Nasional Penanggulangan Bencana. (2012). Master plan Pengurangan Risiko Bencana Tsunami. Jakarta: BNPB.

Balitbang Depdiknas. (2008). Materi Bahan Ajar Gempa Bumi dan Tsunami. Jakarta: Pusat Kurikulum, Balitbang Depdiknas.

Bastaman, H. D. (1996). Meraih hidup bermakna. Jakarta: Paramadina.

Battaglia RA. (2007). Handbook Of Lives Tuck Management. New Jersey: Pearson Prentice Hall.

Boer, R. (2012). Analisis Penilaian Tingkat Kerentanan. Pelatihan Aplikasi Metode Kerentanan. Bogor: CCROMSEAP IPB.

Bollin, C., Cardenas, C., Hahn, H., Vatsa. (2003). Disaster Risk Management By Communities and Local Government. Inter-America Development Bank. New York Avenue.

Bondan. (2006). Keperawatan Gerontik ranah penelitian keperawatan gerontik. Jakarta: PPNI.

Brunner \& Suddarth. (2001). Keperawatan Bedical Bedah. Edisi 8 Vol 1. Jakarta: EGC.

Budiarto, Eko. (2013). Pengantar Epidemiologi. Jakarta: EGC.

Dharma, A. (1990). Introduction to psycchology. Jakarta: Erlangga

Edwards, R., D. (2010). Post Traumatic Stress Disorder (PTSD). MedicineNet.

Endah N. (2014). Play Therapy Untuk Anak-Anak Korban Bencana Alam Yang Mengalami Trauma (Post Traumatic Stress Disorder/PTSD). Jurnal Universitas Islam Bandung, 1(2):164-166.

Foa, E. B., Davidson, J. R. T., \& Frances, A. (1999). The Expert Consensusguideline Series: Treatment Of Posttraumatic Stress Disorder. Journal of Clinical Psychiatry, 60, Supplement 16, 3-76.

Goleman, D. (1995). Emotional Intelligence. New York: Bantam Books.

Hughes, K., \& Batten, L. (2016). The Development of Social and Moral Responsibility in Terms of Respect for the Rights of Others. Jurnal Ilmiah Peuradeun, 4(2), 147-160. doi:10.26811/peuradeun.v4i2.93

Idaiani SM. Kecenderungan Depresi Pada Keluarga Pasien Skizofrenia. Tesis. Semarang: Universitas Diponogoro, Bagian Psikiatri FK.

Inc.Stuart GW. (2009) Principles And Practice Of Psychiatric Nursing. 9 th ed. Missouri : Mosby, Inc. 
IPCC. (2001). Climate change 2001: Impacts, adaptation, and vulnerability: contribution of Working Group II to the third assessment report of the Intergovernmental Panel on Climate Change: Cambridge University Press.

Kaplan, H,I, Sadock, B,J, Grebb, J.A. (2010). Sinopsis Psikiatri Ilmu Pengetahuan Perilaku Psikiatri Klinis. Jakarta:Binarupa Aksara.

Keliat, B.A., Akemat., Helena, N., Nurhaeni, H. (2011). Keperawatan Kesehatan Jiwa Komunitas CMHN Basic Course. Jakarta: EGC.

Konsorsium Pendidikan Bencana. (2011). Kerangka Kerja Sekolah Siaga Bencana. Jakarta: Konsorsium Pendidikan Bencana.

LIPI. (2006). Kajian Kesiapsiagaan Masyarakat dalam Mengantisipasi Bencana Gempabumi dan Tsunami. Jakarta: LIPI.

Maslim R. (2001). Buku Saku Diagnostik Gangguang Jiwa. Rujukan Ringkasan PPDGJ III Jakarta.

Masykur A.M. (2006). Potret Psikososial Korban Gempa 27 Mei 2006 (Sebuah Studi Kualitatif Di Kecamatan Wedi Dan Gantiwarno, Klaten). Jurnal Psikologi Universitas Diponegoro, (3)1:36-43.

Mendatu A, (2010). Pemulihan Trauma: Strategi Penyembuhan Trauma Untuk Diri Sendiri, Anak dan Orang Lain Disekitar Anda. Yogyakarta: Panduan.

Mental Health America. (2007). Post-traumatic Stress Disorder. Mental Health America.

Nasution. (1999). Didatik Azas-Azas Mengajar. Jakarta: Bumi Aksara.

Nilson, R.; Gustafsson, P.E.; dan Svedin, C.G. (2010). Self-Report Potentially Traumatic Live Events and Symptoms of PostTraumatic Stress and Dissociation. Nordic Journal of Psychiatry. 64, 19-26.

Notoatmojo, S. (2007). Promosi Kesehatan dan Ilmu Perilaku. Jakarta: PT. Rineka Cipta.

Notoatmojo, S. (2010). Metodelogi Penelitian Kesehatan. Jakarta: Rineka Cipta.

Nygaard, E., \& Heir, T. (2012). World Assumptions, Posttraumatic Stress And Quality Of Life After A Natural Disaster: A longitudinal study. Health and quality of life outcomes, 10(1), 1. 
Parkinson, F. (2000). Post trauma stress: A personal guide to reduce the longterm effects and hidden damagecaused by violence and disaster. Arizona: Fisher Book.

Rector N.A, Bourdeo D, Kitchen K, Masalan L.J. (2008). Anxiety Disorder An Information Guide. P. 1-13.

Sadock B.J Sadock V.A. (2010). Buku Ajar psikiatri klinis. Ed 2. Jakarta. EGC.

Semiun Y. (2006). Kesehatan Mental 3. Yogyakarta: Kanisius.

Soejono dan Probosuseno. (2009). Depresi pada pasien usia lanjut. Editor. Buku ajar ilmu penyakit dalam. 5 th ed. Jakarta: Pusat penerbitan Departeman Ilmu Penyakit Dalam.

Taufik. (2005). Memahami psiko-Spiritual Korban Bencana di Naggroe Aceh Darussalam. Jurnal Psikologi Undip Vol. 2 No 1. h. 48-54.

Tentama, F. (2014). Dukungan Sosial Dan Post-Traumatic Stress Disorder Pada Remaja Penyintas Gunung Merapi. Jurnal Psikologi Undip. 13(2):133-138.

Van Western CJ, Van Asch TWJ, Soeters R. (2003). Landslide Hazard And Risk Zonation Why is It So Diffucult? Bull. Eng Geol. 10.1007/s10064-005-00230.

Videbeck SL. (2008). Buku Ajar Keperawatan Jiwa. Jakarta: EGC.

Walidin, W., Idris, S., \& Tabrani ZA. (2015). Metodologi Penelitian Kualitatif $\mathcal{E}$ Grounded Theory. Banda Aceh: FTK Ar-Raniry Press.

Weaver, A.J., Flannelly, L.T., dan Preston, J.D. (2003). Counseling Survivors of Traumatic Events: A handbook for pastors and other helping professional. Avenue South, Nashville: Abingdon Press.

Weinstein, J. (2008). In the Best Interest of Children: A Proposal to Transform the Adversarial System. United Stated. Sunway Academic Journal.

Whalley \& Wong's. (1999). Nursing Care of Infant and Children, 6th edition. Philadelphia: Mosby Company.

Wiramihardja, SA. (2005). Pengantar Psikologi Abnormal. Bandung: Refika Aditama. 
p-ISSN: 2338-8617 